\title{
Bronchodilatation induced by deep breaths in relation to transpulmonary pressure and lung volume
}

\author{
C J Duggan, J Chan, A J Whelan, N Berend
}

\begin{abstract}
Induced bronchoconstriction in normal subjects can be transiently reversed by a deep breath (airway hysteresis). The mechanisms of airway hysteresis are not fully understood. The aim of these studies was to determine whether the nature of the deep breath (slow or fast inspiration, five or 10 second breath hold) affects the resultant bronchodilatation. Bronchoconstriction was induced in 10 normal subjects by inhalation of histamine until specific airway conductance (sGaw) was halved (mean (SEM) post-histamine sGaw 0.099 $\left.(0.009) \mathrm{s}^{-1} \mathrm{~cm}_{2} \mathrm{O}^{-1}\right)$. A subsequent deep breath to total lung capacity (TLC) increased sGaw by $57 \%(13 \%)$ and neither the rate of inspiration to TLC nor periods of breath holding at TLC produced a significantly different degree of bronchodilatation. Reducing the volume of the deep breath produced progressively less bronchodilatation and this was no longer significant after a breath to $68 \%(2 \%)$ TLC. To determine whether the volume of the deep breath or the accompanying increase in transpulmonary pressure (PstI) was responsible for the effect on sGaw, subjects were studied with an oesophageal balloon in place with and without their chest strapped. Subjects took a deep breath to a Pstl of $20 \mathrm{~cm} \mathrm{H}_{2} \mathrm{O}$ after bronchoconstriction had been induced by histamine. The degree of bronchodilatation (mean (SEM) \%) was not significantly different (strap on $25(6)$, strap off 36 (5)) even though significantly larger lung volumes (as \% TLC) were reached with the strap off (strap on 57 (2), strap off 78 (3)). These results suggest that PstL rather than lung volume during a deep breath determines airway hysteresis.
\end{abstract}

In 1948 Melville and Caplan ${ }^{1}$ reported that a maximal lung inflation could overcome induced bronchoconstriction in dogs. Nadel and Tierney ${ }^{2}$ subsequently found a similar phenomenon in man. They found that inspiration to total lung capacity (TLC) by normal (non-asthmatic) subjects reduced induced bronchoconstriction but had no effect

*For conversion to SI units for $\mathrm{sGaw}$ : $1 \mathrm{~cm} \mathrm{H}_{2} \mathrm{O}=0.1 \mathrm{kPa}$. on resting airway resistance. Fairshter, ${ }^{3}$ however, found an increase in specific conductance (sGaw) after a breath to TLC in the absence of an induced increase in resting airway tone. These observations are evidence for airway hysteresis - that is, airway calibre will vary according to whether a particular lung volume is reached by deflation from TLC or inflation from a lower lung volume. ${ }^{4}$ In keeping with these findings in vivo, smooth muscle contraction enhances hysteresis in dog airways in vitro. ${ }^{5}$

Several potential factors that could contribute to or be responsible for airway hysteresis have been considered. These include withdrawal of vagal bronchomotor tone, which appears important in the $\operatorname{dog}^{67}$ but less so in man. ${ }^{8}$ The effect of release of bronchodilator cyclo-oxygenase products has also been discounted. ${ }^{3}$ The most plausible explanation is an effect of stretch on airway smooth muscle. Gunst and Russell ${ }^{9}$ have shown that stretching of the dog trachealis muscle results in a diminution of muscle contraction.

In the present study we assessed the effect of the magnitude of inspired lung volume on the inspiration induced bronchodilatation that followed histamine induced bronchoconstriction in normal subjects. We also assessed the effect of breath holding and rapid and slow inspiration, analogous to different conditions of stretch applied to the airway smooth muscle. ${ }^{5}$ Finally, so that we could dissociate and investigate the effects of lung volume and transpulmonary pressure (Pstl), the subjects performed inspiratory manoeuvres to an identical Pstl but different lung volumes by carrying out the manoeuvres with and without the chest tightly strapped. The application of a chest strap is known to increase lung elastic recoil. ${ }^{10-12}$ The mechanism is not clear but does not include airway closure. ${ }^{113}$ It may be related to an alteration of the pleural pressure gradient or to changes in alveolar surface properties. $^{12}$

\section{Methods}

EFFECTS OF LUNG VOLUME, BREATH HOLDING, AND RATE OF INSPIRATION ON HISTAMINE INDUCED BRONCHOCONSTRICTION

Ten normal subjects (age range 21-37 years), with no history of asthma or other respiratory disease, gave informed consent to the protocol, which was approved by the medical ethics review committee of the Repatriation General Hospital, Concord. 
Table 1 Post-histamine specific airway conductance (sGaw; mean (SEM) values) before the inflation manoeuvres

\begin{tabular}{ll}
\hline & $s G a w\left(s^{-1} \mathrm{~cm} \mathrm{H}_{2} \mathrm{O}^{-1}\right)$ \\
\hline$\%$ total lung capacity & \\
$100 \%$ & $0.099(0.008)$ \\
$80 \%$ & $0.093(0.007)$ \\
$60-70 \%$ & $0.107(0.011)$ \\
Inspiration & $0.089(0.009)$ \\
Rapid & $0.101(0.007)$ \\
Slow & $0.092(0.006)$ \\
Breath hold & $0.102(0.009)$ \\
5 seconds & \\
10 seconds & \\
\hline
\end{tabular}

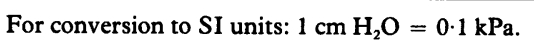

Airway resistance (Raw) and thoracic gas volume (TGV) were measured in a constant volume body plethysmograph from three to five panting breaths according to the methods described by DuBois et al ${ }^{1415}$; specific airway conductance (sGaw) was derived from these values. This was followed by an expiration to residual volume and inspiration to TLC. The subjects then inhaled a variable number of breaths of histamine in concentrations from 8 to $32 \mathrm{mg} / \mathrm{ml}$ using a dosimeter until a decrease in sGaw of at least $30 \%$ was achieved. They were then instructed not to take a deep breath, cough, or sigh before the subsequent controlled deep breath manoeuvre, which was followed by a repeat measurement of sGaw (that is, TGV and Raw) 10 seconds later. The controlled deep breath consisted of the following series of manoeuvres: (1) inspiration to TLC (inspiratory flow at subjects' discretion); (2) inspiration to $80 \%$ TLC, with feedback on an oscilloscope; (3) inspiration to $60-70 \%$ TLC, again with the oscilloscope (originally a volume of $60 \%$ TLC was aimed for, but this was difficult as for some subjects a tidal breath already exceeded $60 \%$ TLC); (4) inspiration to TLC with a five second breath hold at TLC; (5) inspiration to TLC with a 10 second breath hold at TLC; (6) rapid inspiration to TLC (flow rates measured with a pneumotachograph); (7) slow inspiration to TLC, again with measured flow rates.

Figure 1 Change in specific airway conductance (sGaw)that is, the difference between the post-histamine sGaw and sGaw after the various breathing manoeuvres-in 10 normal subjects in whom bronchoconstriction was induced with histamine. Only inspiration to 60Only inspiration to $60-$
$70 \%$ total lung capacity $70 \%$ total lung capacity
(TLC) produced a response significantly different $(p<0.05)$ from that of an inspiration to $100 \%$ TLC.

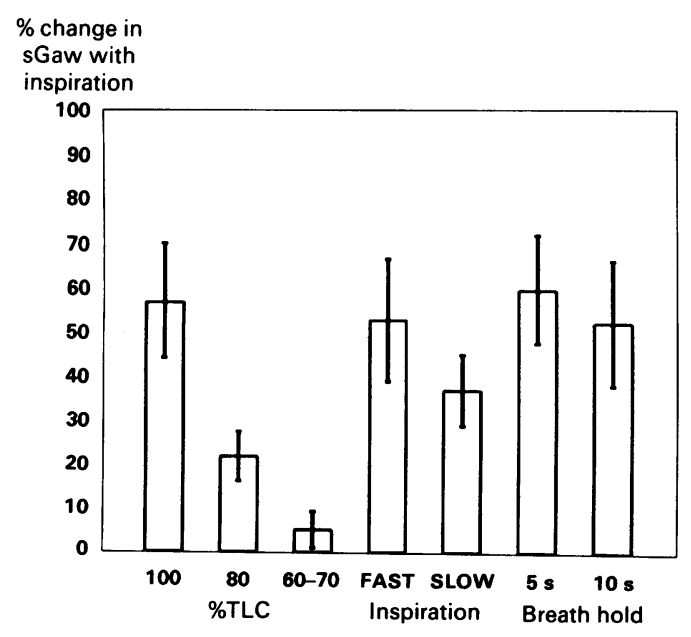

The total duration of the experiments was 1.5-3 hours for each subject. Because of the transitory nature of histamine induced bronchoconstriction more histamine had to be administered intermittently by dosimeter to maintain the bronchoconstriction.

\section{CHEST STRAPPING}

The chest strapping experiments were performed with eight further volunteers at the Royal North Shore Hospital. The subjects (age range 22-35 years) had no history of asthma or respiratory disease and gave informed consent to the protocol, which had been approved by the hospital's medical ethics review committee.

On day 1 baseline Raw, TGV, and TLC were determined in a constant volume body plethysmograph as before. After baseline studies histamine $(5 \mathrm{~g} / 100 \mathrm{ml})$ was administered with a hand held deVilbiss glass nebuliser. From 10 to 30 puffs were given until Raw doubled. An inspiration to TLC with remeasurement of sGaw followed. On day 2 an oesophageal balloon catheter was inserted via the nose to mid oesophagus and connected to one end of a differential pressure transducer (Validyne $\pm 100 \mathrm{~cm} \mathrm{H}_{2} \mathrm{O}$ ), the other end being connected to a side tap at the mouth so that PstL could be recorded. ${ }^{16} \mathrm{~A}$ corset like device was then tightly fastened around the thorax and sGaw and TLC were measured. Histamine was administered as on day 1 . The subjects were then instructed to take a breath to a Pstl of 20 $\mathrm{cm} \mathrm{H}_{2} \mathrm{O}$, lung volume and PstL being recorded on a chart recorder. Ten seconds later (timed with a stop watch from deep breath to shutter closure) sGaw was remeasured. On day 3 the above protocol was repeated without chest strapping - that is, after inhaling histamine the subjects inspired to a PstL of $20 \mathrm{~cm} \mathrm{H}_{2} \mathrm{O}$ but the lung volume reached was now substantially higher than on day 2. The order of the manoeuvres on days 2 and 3 was randomised.

All manoeuvres were performed four to six times and the mean results for all the subjects were analysed.

\section{ANALYSIS}

Changes in sGaw and TLC after the different manoeuvres were compared by analysis of variance with multiple comparisons between groups (Student's-Newman-Keuls test). A p value below 0.05 was accepted as significant.

\section{Results}

All subjects had a $\mathrm{PD}_{20} \mathrm{FEV}_{1}$ for histamine of more than $8 \mathrm{mg} / \mathrm{ml}$. Histamine inhalation was well tolerated, with minimal flushing and hoarseness.

EFFECTS OF LUNG VOLUME, BREATH HOLDING AND RATE OF INSPIRATION ON HISTAMINE INDUCED BRONCHOCONSTRICTION Mean baseline (SEM) sGaw for the 10 subjects was $0 \cdot 205(0.017) \mathrm{s}^{-1} \mathrm{~cm} \mathrm{H}_{2} \mathrm{O}^{-1}$. After histamine inhalation sGaw decreased significantly to $0.099(0.009) \mathrm{s}^{-1} \mathrm{~cm} \mathrm{H}_{2} \mathrm{O}^{-1}(\mathrm{p}<0.001)$-that is, sGaw was approximately halved. There was no significant difference in the post-histamine 
Table 2 Chest strapping study: baseline deep breath responses in terms of specific airway conductance (sGaw) in the eight subjects

\begin{tabular}{|c|c|c|c|c|c|}
\hline \multirow[b]{2}{*}{$\begin{array}{l}\text { Subject } \\
\text { No }\end{array}$} & \multicolumn{3}{|c|}{ sGaw $\left(\mathrm{s}^{-1} \mathrm{~cm} \mathrm{H}_{2} \mathrm{O}^{-1}\right)$} & \multirow[b]{2}{*}{$\begin{array}{l}\% \Delta \\
\text { sGawt }\end{array}$} & \multirow[b]{2}{*}{$\begin{array}{l}T L C \\
(l)\end{array}$} \\
\hline & Baseline & $\begin{array}{l}\text { After } \\
\text { histamine }\end{array}$ & $\begin{array}{l}\text { After } \\
\text { deep breath }\end{array}$ & & \\
\hline 1 & 0.289 & 0.097 & $0 \cdot 136$ & $40 \cdot 2$ & $7 \cdot 01$ \\
\hline 2 & 0.159 & 0.078 & 0.126 & $61 \cdot 5$ & $8 \cdot 28$ \\
\hline 3 & 0.213 & 0.089 & $0 \cdot 166$ & $86 \cdot 5$ & $7 \cdot 50$ \\
\hline 4 & 0.316 & 0.112 & $0 \cdot 186$ & $66 \cdot 1$ & $7 \cdot 02$ \\
\hline 5 & $0 \cdot 148$ & 0.058 & 0.085 & $46 \cdot 6$ & $7 \cdot 36$ \\
\hline 6 & 0.250 & $0 \cdot 110$ & $0 \cdot 169$ & 53.6 & $8 \cdot 20$ \\
\hline 7 & 0.310 & $0 \cdot 114$ & $0 \cdot 196$ & 71.9 & $7 \cdot 00$ \\
\hline 8 & $0 \cdot 270$ & $0 \cdot 103$ & $0 \cdot 175$ & 69.9 & $6 \cdot 30$ \\
\hline Mean & $0 \cdot 244$ & $0.095^{\star}$ & $0 \cdot 155+$ & $62 \cdot 0$ & $7 \cdot 33$ \\
\hline SEM & 0.023 & 0.007 & 0.013 & $5 \cdot 3$ & 0.23 \\
\hline
\end{tabular}

* Significantly different from baseline sGaw $p<0.001$

+ Significantly different from post-histamine sGaw $p<0.001$

$\ddagger \%$ change in sGaw after the deep breath to $100 \%$ total lung capacity (TLC)

Conversion to SI units: $1 \mathrm{~cm} \mathrm{H} \mathrm{H}_{2} \mathrm{O}=0 \cdot 1 \mathrm{kPa}$.

sGaw values before any of the deep breath manoeuvres (table 1). The lung volumes reached during the submaximal inspirations were $80.0(0 \cdot 8)$ and $68.2(2 \cdot 1) \%$ TLC, both significantly less than TLC $(\mathrm{p}<0.01)$. The rapid inspirations to TLC (peak flow 4.3(0.4) 1 $\mathrm{s}^{-1}$, mean inspiratory flow $\left.2 \cdot 7(0 \cdot 3) 1 \mathrm{~s}^{-1}\right)$ were significantly faster $(p<0.001)$ than the slow inspirations (peak flow 1.3 (0.2), mean inspiratory flow $\left.0.6(0 \cdot 1) 1 \mathrm{~s}^{-1}\right)$.

The mean $\% \Delta \mathrm{sGaw}$-that is, the difference between post-histamine sGaw and sGaw after each breathing manoeuvre-is plotted in figure 1. Only the bronchodilator response following a breath to $60-70 \%$ TLC differed significantly from the $100 \%$ TLC response $(\mathrm{p}<0.05)$.

\section{CHEST STRAPPING}

The baseline deep breath responses are shown in table 2. Significant bronchoconstriction occurred after histamine inhalation $(p<0.001)$ with subsequently significant bronchodilatation following a deep breath to TLC ( $p<$ $0.001)$. After application of the chest strap (table 3) and inhalation of histamine sGaw did not differ from the post-histamine sGaw during the baseline responses. Inspiration to a PstL of $19.3(0.6) \mathrm{cm} \mathrm{H}_{2} \mathrm{O}$ increased lung volume to only $56.6 \%(1.8 \%)$ of baseline TLC. This was associated with an increase in sGaw of $25 \%$ (p $<0.01)$. With the chest strap off the posthistamine sGaw was slightly but significantly $(p<0.05)$ lower than with the chest strap

Table 3 Deep breath responses in terms of specific airway conductance (sGaw) with chest strap applied in the eight subjects

\begin{tabular}{|c|c|c|c|c|c|c|c|c|}
\hline \multirow[b]{2}{*}{$\begin{array}{l}\text { Subject } \\
\text { No }\end{array}$} & \multicolumn{3}{|c|}{$s G a w\left(s^{-1} \mathrm{~cm} \mathrm{H}_{2} \mathrm{O}^{-1}\right)$} & \multirow[b]{2}{*}{$\begin{array}{l}\% \Delta \\
\text { sGaw }\end{array}$} & \multirow{2}{*}{$\begin{array}{l}\text { PstL of } \\
\text { deep breath } \\
\left(\mathrm{cm} \mathrm{H}_{2} \mathrm{O}\right)\end{array}$} & \multirow{2}{*}{$\begin{array}{l}\text { Volume (l) } \\
\text { of deep } \\
\text { breath }\end{array}$} & \multirow{2}{*}{$\begin{array}{l}\% \text { baseline } \\
T L C \\
\text { unstrapped }\end{array}$} & \multirow[b]{2}{*}{$\begin{array}{l}\text { Time } \\
(s) \dagger\end{array}$} \\
\hline & $\begin{array}{l}\text { After } \\
\text { histamine }\end{array}$ & $\begin{array}{l}\text { After } \\
\text { breath }\end{array}$ & $\Delta$ & & & & & \\
\hline 1 & $0 \cdot 117$ & $0 \cdot 139$ & 0.022 & $2 \cdot 2$ & $19 \cdot 7$ & $4 \cdot 28$ & 61 & $10 \cdot 8$ \\
\hline 2 & 0.097 & $0 \cdot 103$ & 0.006 & 6.9 & $20 \cdot 2$ & $5 \cdot 25$ & 63 & $8 \cdot 4$ \\
\hline 3 & 0.094 & $0 \cdot 141$ & 0.047 & $49 \cdot 0$ & $19 \cdot 0$ & $4 \cdot 47$ & 60 & $10 \cdot 2$ \\
\hline 4 & 0.098 & $0 \cdot 125$ & 0.027 & $27 \cdot 6$ & $21 \cdot 4$ & $3 \cdot 70$ & 53 & $9 \cdot 6$ \\
\hline 5 & 0.095 & $0 \cdot 104$ & 0.009 & $8 \cdot 3$ & $19 \cdot 8$ & $4 \cdot 28$ & 58 & $9 \cdot 0$ \\
\hline 6 & $0 \cdot 140$ & $0 \cdot 190$ & 0.050 & $35 \cdot 7$ & $16 \cdot 7$ & $4 \cdot 70$ & 57 & 9.9 \\
\hline 7 & $0 \cdot 138$ & $0 \cdot 150$ & 0.012 & $8 \cdot 7$ & $20 \cdot 3$ & 3.35 & 58 & $10 \cdot 0$ \\
\hline 8 & 0.076 & $0 \cdot 110$ & 0.034 & $44 \cdot 7$ & $17 \cdot 2$ & $3 \cdot 40$ & 54 & $10 \cdot 0$ \\
\hline Mean & $0 \cdot 107$ & $0.133^{\star}$ & 0.026 & $25 \cdot 1$ & $19 \cdot 3$ & $4 \cdot 18$ & $56 \cdot 6$ & $9 \cdot 7$ \\
\hline SEM & 0.008 & 0.010 & 0.006 & $6 \cdot 0$ & $0 \cdot 6$ & 0.23 & $1 \cdot 8$ & 0.3 \\
\hline
\end{tabular}

$\star$ Significantly different from post-histamine sGaw $(p<0.01)$

tFrom deep breath to measurement of sGaw.

Conversion to SI units: $1 \mathrm{~cm} \mathrm{H} \mathrm{H}_{2} \mathrm{O}=0.1 \mathrm{kPa}$.

PstL-transpulmonary pressure; TLC-total lung capacity.

Table 4 Deep breath responses in terms of specific airway conductance (sGaw) without chest strap applied in the eight subjects

\begin{tabular}{|c|c|c|c|c|c|c|c|c|}
\hline \multirow[b]{2}{*}{$\begin{array}{l}\text { Subject } \\
\text { No }\end{array}$} & \multicolumn{3}{|c|}{ sGaw $\left(\mathrm{s}^{-1} \mathrm{~cm} \mathrm{H}_{2} \mathrm{O}^{-1}\right)$} & \multirow[b]{2}{*}{$\begin{array}{l}\% \Delta \\
\text { sGaw }\end{array}$} & \multirow{2}{*}{$\begin{array}{l}\text { PstL of } \\
\text { deep breath } \\
\left(\mathrm{cm} \mathrm{H} \mathrm{H}_{2} \mathrm{O}\right)\end{array}$} & \multirow{2}{*}{$\begin{array}{l}\text { Volume (l) } \\
\text { of deep } \\
\text { breath }\end{array}$} & \multirow{2}{*}{$\begin{array}{l}\% \text { baseline } \\
T L C \\
\text { unstrapped }\end{array}$} & \multirow[b]{2}{*}{$\begin{array}{l}\text { Time } \\
(s) \dagger\end{array}$} \\
\hline & $\begin{array}{l}\text { After } \\
\text { histamine }\end{array}$ & $\begin{array}{l}\text { After } \\
\text { breath }\end{array}$ & $\Delta$ & & & & & \\
\hline 1 & $0 \cdot 123$ & $0 \cdot 197$ & 0.074 & 61.5 & $20 \cdot 3$ & $5 \cdot 26$ & 75 & 11.0 \\
\hline 2 & 0.069 & 0.083 & 0.015 & $21 \cdot 9$ & $22 \cdot 1$ & 6.35 & 77 & $11 \cdot 4$ \\
\hline 3 & 0.071 & $0 \cdot 102$ & 0.031 & $43 \cdot 1$ & 21.5 & 5.95 & 80 & $10 \cdot 8$ \\
\hline 4 & 0.096 & 0.135 & 0.039 & $40 \cdot 6$ & $20 \cdot 6$ & 4.90 & 70 & 8.9 \\
\hline 5 & 0.042 & 0.051 & 0.009 & $21 \cdot 0$ & $22 \cdot 6$ & $6 \cdot 65$ & 90 & 10.5 \\
\hline 6 & 0.095 & 0.125 & 0.030 & 31.6 & $22 \cdot 1$ & $7 \cdot 16$ & 87 & $9 \cdot 7$ \\
\hline 7 & $0 \cdot 140$ & $0 \cdot 170$ & 0.030 & $21 \cdot 4$ & $19 \cdot 3$ & $4 \cdot 60$ & 66 & $9 \cdot 8$ \\
\hline 8 & 0.068 & $0 \cdot 100$ & 0.032 & $47 \cdot 1$ & $19 \cdot 6$ & $4 \cdot 80$ & 76 & $9 \cdot 4$ \\
\hline Mean & 0.088 & $0 \cdot 120^{\star}$ & 0.033 & $36 \cdot 0$ & $21 \cdot 0$ & $5 \cdot 71$ & $77 \cdot 6$ & $10 \cdot 2$ \\
\hline SEM & 0.011 & 0.017 & 0.007 & $5 \cdot 2$ & 0.4 & 0.34 & $2 \cdot 8$ & 0.3 \\
\hline
\end{tabular}

^Significantly different from post-histamine sGaw $(\mathrm{p}<0.001)$

†From deep breath to measurement of sGaw.

Conversion to SI units: $1 \mathrm{~cm} \mathrm{H} \mathrm{H}_{2} \mathrm{O}=0.1 \mathrm{kPa}$.

PstL-transpulmonary pressure; TLC-total lung capacity. 
Figure 2 Percentage increase in specific airway conductance (sGaw) after inspiration to various lung volumes. Open circles indicate values without a chest strap; the closed circle indicates the value following inspiration to a transpulmonary pressure (PstL) of $20 \mathrm{~cm} \mathrm{H}_{2} \mathrm{O}$ with a chest strap applied; and the square indicates the value following inspiration to a PstL of $20 \mathrm{~cm} \mathrm{H}_{2} \mathrm{O}$ without a chest strap.

Conversion to SI units

$1 \mathrm{~cm} \mathrm{H}_{2} \mathrm{O}=0.1 \mathrm{kPa}$.

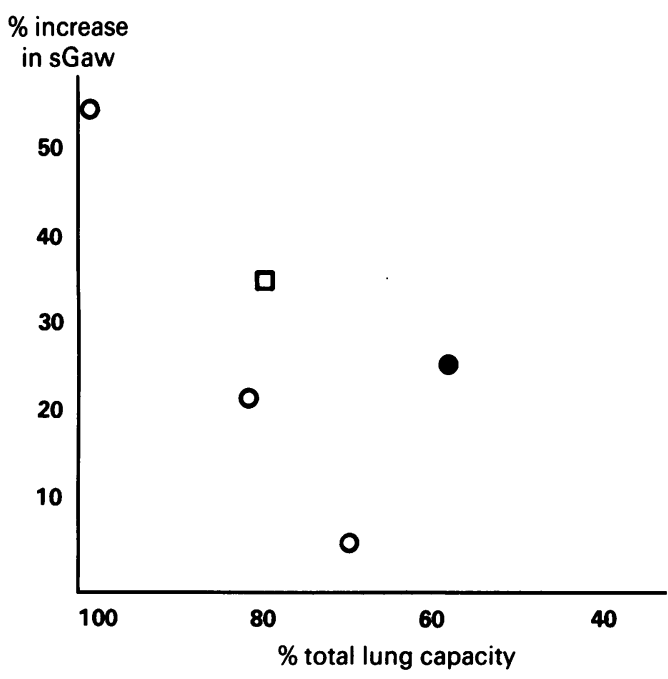

applied (table 4). Inspiration to a Psti of 21.0 $(0.4) \mathrm{cm} \mathrm{H}_{2} \mathrm{O}$ (which did not differ from the Pstl with the chest strap applied) was associated with an increase in lung volume to $77 \cdot 6 \%(2 \cdot 8 \%)$ baseline TLC, which was significantly higher $(p<0.001)$ than the volume achieved with the chest strapped. This manoeuvre was associated with an increase in sGaw of $36 \%(p<0.001)$. There was no significant difference between the $\%$ change in sGaw with and without the chest strap ( $p=$ 0.08 ). These results are depicted graphically in figure 2. As the post-histamine $\mathrm{sGaw}$ values were different with and without the chest strap, the absolute changes in sGaw in response to the breath were also compared. Again, there was no significant difference $(p=0.43)$.

\section{Discussion}

This study has shown that in normal subjects deep breath induced bronchodilatation depends on the lung volume reached, being significantly smaller at volumes below $70 \%$ TLC. The rate of inspiration to TLC and a period of breath holding at TLC did not influence the degree of bronchodilatation significantly. Finally, the chest strapping study suggested that the increase in Pstl rather than lung volume is responsible for the bronchodilatation.

We had to consider whether airway conductance or specific conductance was the more appropriate expression of airway calibre in these studies. None of the bronchodilator responses that followed the deep breath manoeuvres was associated with a significant change in FRC, suggesting that either measurement would be reasonable. sGaw was chosen because it reduced the interindividual variability. The statistical results using Gaw, however, were identical in pattern to those using sGaw.

The main potential source of error in the experiments lay in the possibility that subjects would fail to attain the correct volumes and Pstl on inspiration. With appropriate instruction and visual feedback accuracy proved to be not too difficult and we obtained values close to those desired. The $60-70 \%$ TLC inspirations were a little more difficult as this was quite close to the end of normal tidal breath for many of the subjects. It has previously been shown that the increase in sGaw after a deep breath is maximum at the earliest possible measurement (about seven seconds) after the deep breath and that it then declines non-linearly with time until it approaches the preinflation value by 60 seconds. ${ }^{1718}$ The measurements were therefore timed with a stopwatch and made as close as possible to 10 seconds after the peak of the inspiration.

The initial part of this study clearly showed that the change in sGaw was related to the depth of the previous inspiration. Although Butler et al in $1960^{19}$ showed in man that lung elastic recoil was responsible for the relation between airway conductance and lung volume, the emphasis subsequently has in general been on the effects of lung volume. Bouhuys and colleagues $^{20}$ suggested that the use of partial expiratory flow-volume curves initiated from $60 \%$ TLC may be a more sensitive index of bronchoconstriction than measurements made from manoeuvres begun at TLC. This technique, which has subsequently become widely used, focuses attention on the relation of flow to lung volume. Previous work, however, suggests that PstL and the stretch applied to airway smooth muscle rather than lung volume is the cause of the observed airway hysteresis. 5921 The present study clearly shows that inspiration to the same Pstl with widely different lung volumes and with a chest strap on and off results in similar increases in sGaw. The slightly (but not significantly) larger change in sGaw (36\% versus $25 \%$ ) with the chest strap removed raises the possibility of a type II error. The first part of the study, however, showed that inspiration to only $60-70 \%$ TLC does not lead to significant bronchodilatation, yet with the chest strap applied inspiration to only $56.6 \%$ TLC resulted in a significant increase in sGaw. Thus the group data point to PstL as the determining factor and make the possibility of a type II error less likely.

Closer inspection of the individual responses with the chest strap applied (table 2) shows that the subjects can be divided into two groups. Subjects 1, 2, 5, and 7 had minimal bronchodilator responses whereas subjects $3,4,6$, and 8 had responses similar to the ones they had with the chest strap removed (table 3 ). We could find no feature of these subjects to explain these different responses. With the extreme degree of chest constriction induced by the strap, however, considerable chest wall and lung distortion must have resulted. This may have varied, depending on the chest configuration and chest wall compliance of each subject, and may serve to explain some of these differences by introducing regional inhomogeneities of transmural airway pressures. ${ }^{11}$

The effects of rate of inspiration (or rate of change of PstL) have been examined in vitro and in vivo previously. Sasaki and Hoppin ${ }^{5}$ cycled precontracted dog airways through a range of simulated breath frequencies and volumes. The range of frequencies was from 
0.0017 to $1 \mathrm{~Hz}$. They showed that the degree of hysteresis of airway cross sectional area depended on cycling frequency, with the greatest hysteresis observed at a slow $0.017 \mathrm{~Hz}$. By contrast, Hida et $a l^{22}$ and Beaupré and Orehek ${ }^{23}$ found greater bronchodilatation in vivo after a rapid inspiration than after a slow inspiration. This difference may well be explained by the relatively greater transmural airway pressures generated by rapid inspiration, particularly across narrowed airways. It may also explain the observation that the magnitude of the deep breath effect depends on the degree of induced airway narrowing. ${ }^{23}$ One further explanation for the difference in deep breath responses between dog and human lungs may be related to the different contributions of airway resistance and tissue viscance. After bronchoconstriction has been induced in the dog a deep breath results in a pronounced decrease in tissue viscance, ${ }^{24}$ whereas in man it is the airway resistance that falls. ${ }^{25}$ This could contribute to different responses at different cycling frequencies.

In this study there was a trend for the fast inspiration to produce a greater change in sGaw but this did not reach statistical significance. This may in part be due to the smaller difference between the fast and the slow flow rates in our study than in that of Hida $e t$ $a l .{ }^{22}$ Because of the lack of statistical difference in sGaw responses between the slow and the fast inspirations, inspiratory flow rates were not tightly controlled in the chest strapping study. Possibly the subjects inspired more slowly with the chest strap applied, and this may also have contributed to the trend for the change in sGaw to be less with the chest strap applied. The Pstl of $20 \mathrm{~cm} \mathrm{H}_{2} \mathrm{O}$ in the strapping study was static at the end of the inspiration. Transmural airway pressures during the dynamic manoeuvre would have been higher with a fast inspiration.

Several previous studies have shown that the degree of bronchodilatation decreases with time of breath holding before expiration, ${ }^{2426}$ though the studies of Beaupré and Orehek ${ }^{23}$ were performed in asthmatic subjects. The difference in sGaw in our study between a 5 second and a 10 second breath hold was minimal and not significant. These results are of some practical importance because a considerable variation in inspiratory flow and breath holding, within the ranges that may be found in normal individuals and those with airflow limitation, does not produce large changes in sGaw, minimising a further potential complexity in the interpretation of the results of lung function tests.

In the normal lung volume and Pstl are linked by a defined pressure-volume relation. The practical importance of the findings may be in relation to conditions such as acute asthma and reactions to inhaled bronchoconstricting agents, when the pressure-volume curve may shift and inhalation to a given lung volume may result in a different PstL. This may be one reason for the different deep breath responses shown by patients with asthma. ${ }^{1727}$

We thank B Karet, G Hanna, R Simmul, W D Castle, $M$ Parmentier, and C Phillips for valuable technical assistance and C Taylor for typing the manuscript.

1 Melville KI, Caplan H. The influence of lung distension upon response of bronchioles to epinephrine and to histamine. J Pharmacol Exp Ther 1948;94:182-91.

2 Nadel JA, Tierney DF. Effect of a previous deep inspiration on airway resistance in man. J Appl Physiol 1961;16: $717-9$.

3 Fairshter RD. Airway hysteresis in normal subjects and individuals with chronic airflow limitation. J Appl Physiol 1985;58:1505-10.

4 Vincent NJ, Knudson R, Leith DE, Macklem PT, Mead J. Factors influencing pulmonary resistance. J Appl Physiol 1970;29:236-43.

5 Sasaki H, Hoppin FG Jr. Hysteresis of contracted airway smooth muscle. J Appl Physiol 1979;47:1251-62.

6 Bowes G, Shakin EJ, Phillipson EA, Zamel N. An efferent pathway mediating reflex tracheal dilation in awake dogs. J Appl Physiol 1984;57:413-8.

7 Hahn HL, Graf PD, Nadel JA. Effect of vagal tone on airway diameters and on lung volume in anaesthetised dogs. $J$ Appl Physiol 1976;41:581-9.

8 Day A, Zamel N. Failure of cholinergic blockade to prevent bronchodilatation following deep inspiration. $J A p p l$ Physiol 1985;58:1449-52.

9 Gunst SJ, Russell JA. Contractile force of canine trachea smooth muscle during continuous stretch. J Appl Physiol 1982;52:655-63.

10 Caro GC, Butler J, DuBois AB. Some effects of restriction of chest cage expansion on pulmonary function in man: an experimental study. J Clin Invest 1960;39:573-83.

11 Sybrecht GW, Garrett L, Authonisen NR. Effect of chest strapping on regional lung function. J Appl Physio 1975;39:707-13.

12 Stubbs SE, Hyatt RE. Effect of increased recoil pressure on maximal expiratory flow in normal subjects. $J$ Appl Physiol 1972;32:325-31.

13 Manco JC, Hyatt RE. Relationship of air trapping to increased lung recoil induced by chest cage restriction. $\mathrm{Am}$ Rev Respir Dis 1975;111:21-6.

14 DuBois AB, Bothelo SY, Comroe JH Jr. A new method for measuring airway resistance in man using a body plethysmograph: values in normal subjects and in patients with respiratory disease. J Clin Invest 1956;35:327-35.

15 DuBois AB, Bothelo SY, Bedel GN, Marshall R, Comroe JH Jr. A rapid plethysmographic method for measuring functional residual capacity in normal subjects. $J$ Clin Invest 1956;35:322-6.

16 Milic-Emili J, Mead J, Turner JM, Glauser EM. Improved technique for estimating pleural pressure from oesophageal balloons. J Appl Physiol 1964;19:207-11.

17 Fish JE, Ankin MG, Kelly JF, Peterman VI. Regulation of bronchomotor tone by lung inflation in asthmatic and non-asthmatic subjects. J Appl Physiol 1981;50:1079-86.

18 Parham WM, Shephard RH, Norman PS, Fish JE. Analysis of time course and magnitude of lung inflation effects on airway tone: Relation to airway reactivity. Am Rev Respir Dis 1983;128:240-5.

19 Butler J, Caro CG, Alcala R, Du Bois AB. Physiological factors affecting airway resistance in normal subjects and in patients with obstructive respiratory disease. $J$ Clin Invest 1960;39:584-91.

20 Bouhuys A, Hunt VR, Kim BM, Zapletal A. Maximum expiratory flow rates in induced bronchoconstriction in man. J Clin Invest 1969;48:1159-68.

21 Gunst SJ, Mitzner W. Mechanical properties of contracted canine bronchial segments in vitro. J Appl Physiol 1981; 50:1236-47.

22 Hida W, Aria M, Shindok C, Liu U-N, Sasaki H, Takishima $T$. Effect of inspiratory flow rate on bronchomotor tone in normal and asthmatic subjects. Thorax 1984;39:86-92.

23 Beaupre A, Orehek J. Factors influencing the bronchodilator effect of a deep inspiration in asthmatic patients with provoked bronchoconstriction. Thorax 1982;37:124-8.

24 Ludwig MS, Dreshaj I, Solway J, Munoz A, Ingram RH Jr. Partitioning of pulmonary resistance during constriction in the dog: effects of volume history. J Appl Physiol 1987;62:807-15.

25 Kariya ST, Thompson LM, Ingenito EP, Ingram RH Jr. Effects of lung volume, volume history, and methacholine on lung tissue viscance. J Appl Physiol 1989;66:977-82.

26 Green M, Mead J. Time dependence of flow volume curves. J Appl Physiol 1974;37:793-7.

27 Orehek J, Charpin D, Velardocchio JM, Grimaud C. Bronchomotor effect of bronchoconstriction-induced deep inspirations in asthmatics. Am Rev Respir Dis 1980;121:297-305. 